\title{
Students Involved in Animal Breeding
}

\author{
Mirela Emilia CADAR*, Anamaria VÂTCĂ, Ilie CORNIOU, Ancuța ROTARU, Ionel TOADER \\ Faculty of Animal Science and Biotechnologies, University of Agricultural Sciences and Veterinary \\ Medicine, 3-5 Mănăştur Street, 400372 Cluj-Napoca, Romania \\ *corresponding author: mirucadar@yahoo.com
}

Bulletin UASVM series Agriculture 73(2)/2016

Print ISSN 1843-5246;

Electronic ISSN 1843-5386

DOI 10.15835/buasvmcn-agr: 12394

\begin{abstract}
In last decade, Romanian agriculture does not follow entirely the European and programs as concerns land exploitation and animal farming (SAPARD). Restrictive development projects (POS-MEDIU, POS-DRU, POSCCE) were active only in large private farms, which represent only $10.7 \%$ of the total registered farms in Romania. Was used a questionnaire for 36 students of our faculty, which have animal farms in 7 counties in Northwest of Transylvania. The study want to put into evidence the current problems of farmers in conditions of some private farms with small and middle number of animals. As small farms, they do not obtain important productions because of financial resource absence, limited professional education and absence of association in bigger exploitation farms. In these situations, the government must react providing a legal frame for rural agricultural development, supporting and supervising these small exploitations.
\end{abstract}

Keywords: animal breeding, private farms, students

Introduction. Current data sometimes are not relevant for the private farms' potential, because many farmers are to insolvency limit as result of production costs and bad capitalization of obtained products (http://statistici.insse.ro/). The state help is minimal and the competition with foreign agricultural products' prices cannot guarantee the prosperity of our agriculture and animal breeding.

Aims and objectives. The study want to put into evidence the conditions of farmers to survive with a minimal government support, farmers which are also students.

Material and methods. The study consisted in a questionnaire for 36 students of our faculty. These students were randomly chosen and have farms for animal breeding in 7 counties in Northwest of Transylvania (Alba, Bihor, Cluj, Maramureş, Mureş, Satu-Mare and Sălaj). The questions referred to: the age of farmers, how many family members work in farm, their professional qualification, the animal species bred in farm, number of animals per species, the obtained production, destination of products and capitalization prices, the subventions for farmers and the monthly income obtained from production. The data were collected during 2012-2014 timeperiods and were mathematically processed.

Results and discussion. The student-farmers are relatively young, $50 \%$ being $20-30$ years old, $22.2 \%$ being $31-40$ years old and $27.8 \%$ being 41-60 years old. The great difference in favour of young farmers is justified by the aim to obtain the professional qualification required to access European founds, which some time are vital for their farm surviving. The farmers' families are composed in average of 4 members, of whom 2 work exclusively in farm. It was observed that inside $50 \%$ of families, two/three members are young and one/two is/are old (parents). In 2014, the total Romania population was 21,640 millions, of whom $47.12 \%$ were in rural regions and only $6.15 \%$ were active in agriculture (www.faostat3. fao.org/; http://www.madr.ro/docs/agricultura/ agricultura-romaniei-2014.pdf). The number of animal species bred in farms are: 374 dairy cows 
Tab. 1. Species bred in studied farms

\begin{tabular}{lcccccccccc}
\hline \multirow{2}{*}{ Counties } & \multicolumn{10}{c}{ Species (capita, families) } \\
\cline { 2 - 14 } & cows & horses buffaloes & pigs & sheep & goats & fowls & rabbits & fish & honeybees \\
\hline Alba & 148 & 0 & 0 & 20 & 0 & 0 & 55 & 0 & 0 & 0 \\
\hline Bihor & 10 & 2 & 0 & 9 & 0 & 0 & 110 & 0 & 0 & 0 \\
\hline Cluj & 72 & 2 & 0 & 17 & 500 & 0 & 2,065 & 0 & 0 & 200 \\
\hline Maramureş & 42 & 1 & 0 & 20 & 200 & 250 & 270 & 2 & 0 & 0 \\
\hline Mureş & 33 & 1 & 0 & 24 & 200 & 12 & 70 & 15 & 0 & 0 \\
\hline Satu-Mare & 52 & 5 & 0 & 43 & 89 & 2 & 275 & 39 & 0 & 55 \\
\hline Sălaj & 17 & 5 & 3 & 20 & 580 & 50 & 235 & 2 & 0 & 0 \\
\hline TOTAL & 374 & 16 & 3 & 153 & 1,569 & 314 & 3,080 & 58 & 0 & 255 \\
\hline
\end{tabular}

(39.6\% in Alba, 19.3\% in Cluj, 15.5\% in Mureş), 16 horses (62.4\% in Mureș and Sălaj), 3 buffaloes (100\% in Sălaj), 153 pigs (30.9\% in Mureş), 1,569 sheep (36.9\% in Sălaj, 31.9\% in Cluj), 314 goats (79.6\% in Maramureş), 3,080 poultry (67\% in Cluj), 58 rabbits (55.2\% in Mureş), 255 honeybees families (78.4\% in Cluj and $21.6 \%$ in Satu-Mare) and no fish farms (Tab. 1). The species number is very different because of region tradition and land surface for animal fodder. The obtained production as income source is secondary for $55.6 \%$ of farmers, it is principal for $38.9 \%$ of farmers and $5.5 \%$ of farmers do not give any response. As concerns the products' destination, $36.5 \%$ of farmers used the products for personal consumption, $61.5 \%$ of farmers choose to sell and among these ones only $31.25 \%$ choose the both variants. The capitalization prices varied very much depending on buyer, thus in 20 cases the products were bought by collecting centers at prices from below 1 Ron (70\%), to 1-5 Ron (25\%) and 10-15 Ron $(5 \%)$ or by subscribers at prices from below 1 Ron (25\%), to 1-5 Ron (50\%), 5-10 Ron (12.5\%) and 10-15 Ron (12.5\%) and as secondary products have increased prices to 5-10 Ron (26.7\%), 10-15 Ron (46.7\%) and over 15 Ron (26.6\%).

The majority of farmers were beneficiaries of governmental subventions with values between 28 and 500 Ron, depending on animal species and geographical zone. The monthly income obtained from production also varied depending on the county and farm production capacity, so 4 farmers $(11.1 \%)$ from three counties (Mureş, Cluj and Sălaj) hardly obtained incomes below 250 Ron, 8 farmers $(22.2 \%)$ from five counties obtained in- comes of 250-500 Ron, 9 farmers (25\%) from five counties obtained incomes of 500-1,000 Ron, 13 farmers $(36.1 \%)$ from all counties obtained incomes over 1,000 Ron, one farmer registered loss in last two years and one farmer did not respond. So, the question is: how could they survive in these conditions? Statistically, more than $42 \%$ of farmers' family members have two jobs, the second one being farm outside. In time, it was observed that farmers refuse to associate into large land and animals exploitations, but in last 5 years, in Romania, there are established few large farms $(16,464=0.42 \%)$ (http: //statistici.insse.ro/), which can compete on European markets, and which could be very good examples for a modern agriculture development.

Conclusion. It is obvious that in Romania (as is stipulated in PNDR 2007-2013 program http:// www.pndr.ro/pndr-2007-2013.html) are necessary substantial investments to consolidate the agricultural exploitations, especially for environment protection, animal hygiene and welfare, use of new technologies to improve product quality with a view to reduce the production costs and to increase products' value on competition markets.

Acknowledgments. We want to thank to our students for their patience and agreement to collect and provide the necessary data for our study.

\section{REFERENCES}

1. www.faostat3.fao.org/

2. http://statistici.insse.ro/

3. http://www.madr.ro/docs/agricultura/agriculturaromaniei-2014.pdf

4. http://www.pndr.ro/pndr-2007-2013.html 